\title{
Peranan Keluarga terhadap Prestasi Siswa pada Mata Pelajaran Ilmu Pengetahuan Sosial
}

\author{
Siti Nur Faizah Maghfiroh, Ahmad Farohi, Nova Okta Afriyani, Arghob Khofya Haqiqi \\ Institut Agama Islam Negeri Kudus \\ sitinurfaizah110@gmail.com
}

Naskah diterima: 8 Juni 2019, direvisi: 12 Oktober 2019, disetujui: 4 November 2019

\begin{abstract}
This study aims to determine the role of family on student achievement in social studies subjects. The study was conducted using qualitative methods through interview techniques as data collection instruments. The study was conducted at State Junior High School 1 Mejobo, Kudus Regency. This case study research was conducted at State Junior High School 1 Mejobo Kudus with a research method using qualitative research methods. The research method used is the naturalistic method, which is research that originates from the aspect of phenomenology and seeks to understand the meaning of events or problems and their relationship to the object of research. Data collection techniques aside from using observation were also carried out through deep interviews. The results showed that the family is the main place for the formation of student character. The process of forming good character requires good communication between children and other family members. The attitude of parents in caring for and educating children greatly influences the increase in children's intelligence and creativity. Children's intelligence and creativity affect student achievement in social studies subjects.
\end{abstract}

Keywords: Social Studies Subjects, Achievement, Family.

\begin{abstract}
Abstrak
Penelitian ini bertujuan untuk mengetahui peran keluarga terhadap prestasi siswa pada mata pelajaran IPS. Penelitian dilakukan dengan menggunakan metode kualitatif melalui teknik wawancara sebagai instrumen pengumpulan data. Penelitian dilaksanakan di SMPN 1 Mejobo, Kabupaten Kudus. Penelitian studi kasus ini dilakukan di SMPN 1 Mejobo Kudus dengan metode penelitian dengan menggunakan metode penelitian kualitatif. Metode penelitian yang digunakan adalah metode naturalistik, yaitu penelitian yang bersumber pada aspek fenomenologi dan berusaha memahami arti peristiwa atau permasalahan dan hubungannya terhadap obyek penelitian. Teknik pengumpulan data di samping dengan menggunakan observasi juga dilakukan melalui deep interview. Hasil penelitian menunjukkan bahwa keluarga merupakan tempat utama untuk pembentukan karakter siswa. Proses pembentukan karakter yang baik memerlukan komunikasi yang baik antara anak dengan anggota keluarga lainnya. Sikap orangtua dalam mengasuh dan mendidik anak sangat memengaruhi peningkatan kecerdasan dan kreativitas anak. Kecerdasan dan kreativitas anak berperan terhadap prestasi siswa pada mata pelajaran Ilmu Pengetahuan Sosial.
\end{abstract}

Kata Kunci: Mata pelajaran IPS, Prestasi, Keluarga. 


\section{PENDAHULUAN}

Pengaruh lingkungan sangat signifikan dalam proses belajar. Lingkungan adalah laboraturium alami yang memiliki dampak positif sehingga dapat mempermudah proses belajar. Namun, di samping itu juga memiliki dampak negatif yang bisa mengakibatkan kesulitan belajar bagi anak. Dalam kenyataannya guru hanya berperan dan bertanggungjawab pada waktu pelaksanaan proses belajar di sekolah saja, sedangkan mayoritas waktu siswa lebih banyak dihabiskan di lingkungan keluarga dan lingkungan masyarakat. Sehingga untuk mencapai keberhasilan dalam pendidikan, siswa sangat membutuhkan dukungan dan partisipasi aktif dari keluarga dan masyarakat.

Menurut Slameto (2010: 54-60), prestasi belajar dipengaruhi oleh banyak faktor baik dari dalam maupun luar diri siswa. Faktor yang memengaruhi hasil belajar dibedakan menjadi dua yaitu faktor internal dan faktor eksternal. Faktor internal adalah faktor yang berasal dari dalam diri siswa, seperti disiplin belajar, kondisi fisiologis (keadaan fisik siswa), kondisi psikologi (kecerdasan, bakat, minat, motivasi). Faktor eksternal adalah faktor yang berasal dari luar diri siswa, seperti faktor lingkungan, keluarga, alat instrumen (kurikulum, sarana dan prasarana serta pendidik).

Selain itu, keberhasilan siswa dalam mencapai prestasi dalam belajar dipengaruhi oleh beberapa hal, yaitu tingkat (intelektual) kecerdasan yang bagus, pelajaran sesuai dengan bakat yang melekat pada diri, ada minat dan perhatian dalam pembelajaran, motivasi yang baik di dalam belajar, cara belajar yang baik dan strategi yang benar dalam pembelajaran yang dikembangkan oleh guru. Keluarga yang mendukung anak untuk berkembang lebih baik, iklim lingkungan sekolah yang tertib, teratur, dan disiplin adalah pendorong dalam proses pencapaian prestasi belajar. Prestasi belajar tidak hanya dipengaruhi oleh disiplin, tetapi juga dipengaruhi oleh lingkungan keluarga. Siswa yang memiliki disiplin belajar yang kuat mempunyai hubungan yang erat dengan pendidikan atau penanaman disiplin yang dimulai dari keluarga sejak kanak-kanak dan berkembang sehingga menjadi disiplin yang semakin baik (Ni Nyoman Wulan Swidiana Sari Widana, 2016: 11).

Motivasi belajar adalah dorongan dalam diri siswa yang dapat menimbulkan kegiatan dan arah belajar untuk mencapai prestasi hasil belajar yang optimal. Motivasi mendorong minat belajar untuk tercapainya suatu tujuan. Siswa akan sungguh-sungguh dalam belajar karena termotivasi. Motivasi belajar akan sangat menentukan intensitas belajar siswa.

Pemberian motivasi yang tepat pada peserta didik akan sangat mendukung semangat belajarnya dan memberikan dorongan pada peserta didik untuk mencapai prestasi yang optimal. Guru dapat menumbuhkan motivasi belajr siswa dengan berbagai cara, salah satu cara yang dapat dilakukan adalah dengan memberikan reward kepada siswa yang dapat meraih prestasi yang tinggi. Dengan demikian siswa yang lain akan termotivasi untuk lebih giat belajar untuk dapat meraih prestasi yang lebih baik lagi. Motivasi belajar yang kuat dalam diri peserta didik akan mendorong peserta didik lebih semangat dalam belajar dan meraih prestasi belajar yang optimal. "Peserta didik yang memiliki motivasi belajar yang tinggi akan memiliki banyak energi positif dan konsentrasi yang kuat saat proses pembelajaran di sekolah (Sardiman, 2004)."

Faktor utama yang dapat menunjang keberhasilan proses pendidikan yaitu keluarga. Sebagai wilayah terkecil di dalam unsur masyarakat, bentuk dan suasana keluarga ikut serta mewarnai masyarakat. Kehidupan keluarga mewajibkan adanya perencanaan, penataan, dan peningkatan, termasuk yaitu dalam cara pengasuhan kepada anak. Secara alami anak untuk pertama kali akan beraktivitas dengan orang dewasa yang disebut sebagai orangtua, sehingga bisa dikatakan bahwa di dalam keluarga, orangtua adalah orang pertama yang bertanggung jawab terhadap pembangunan dasar-dasar pembentukan sikap, tingkah laku, watak, kepribadan, moral, dan pendidikan pada anakanaknya yang memungkinkan mereka besar sebagai generasi yang cerdas, kreatif, dan mandiri. Hubungannya dengan prestasi belajar siswa, faktor keluarga mempunyai peranan yang sangat penting. Keadaan keluarga akan 
menentukan berhasil atau tidaknya anak dalam menjalani proses belajar. Kondisi keluarga yang bermacam-macam ikut serta menentukan bagaimana hakikat belajar yang dialami dan dicapai oleh anak.

Chasiyah dkk (2009: 81) mengemukakan bahwa "fungsi dasar keluarga adalah memberikan rasa memiliki, rasa aman, kasih sayang dan mengembangkan hubungan yang baik diantara anggota keluarga". Anak merupakan tanggung jawab orangtua, maka dari itu orangtua harus berusaha untuk memberikan yang terbaik untuk anak-anak mereka. Keluarga memiliki peranan yang sangat penting dalam pendidikan anak, karena keluarga, terutama orangtua adalah lingkungan serta orang yang pertama kali dikenal oleh anak, sehingga pendidikan dasar merupakan tanggung jawab orang tua.

Menurut Walgito (2004: 98-99), "Perhatian adalah pemusatan atau konsentrasi dan seluruh aktivitas individu yang ditujukan pada sesuatu atau sekumpulan objek". Perhatian orangtua adalah suatu aktivitas yang tertuju pada suatu hal dalam hal ini adalah aktivitas anak dalam belajar yang dilakukan oleh orangtuanya. Orangtua bisa berarti ayah, ibu atau wali dalam keluarga yang bertanggung jawab atas pendidikan anaknya. Perhatian, kasih sayang, materi harus secara seimbang diberikan oleh orangtua kepada anak-anaknya.

Tersedianya fasilitas belajar dan lingkungan belajar yang nyaman, tenang dan aman akan mendukung siswa agar lebih semangat di dalam proses belajar dan menggapai prestasi. Selain itu, perlu adanya perhatian dengan kegiatan anak karena fasilitas yang mewah jika tidak digunakan dengan baik, maka tidak akan dapat mendongkrak prestasi belajar siswa. Perhatian orangtua dalam aktivitas belajar anak di rumah mempunyai peran yang sangat penting untuk meningkatkan semangat anak dalam meraih prestasi belajar. "Keberhasilan belajar anak di sekolah harus didukung orangtua, baik psikologis maupun pemenuhan fasilitas belajar (Siska Eko Mawarsih, dkk, 2013: 5)".

Sekolah Menengah Pertama Negeri (SMPN) 1 Mejobo merupakan salah satu sekolah menengah pertama di Kabupeten Kudus. Peserta didik SMPN 1 Mejobo memiliki latar belakang yang beragam, latar belakang orangtua, latar belakang prestasi belajar dan lain-lain. Penelitian ini bertujuan untuk (1) Mengetahui peran perhatian orangtua (keluarga) terhadap prestasi belajar siswa SMPN 1 Mejobo (2) Mengetahui peran motivasi belajar terhadap prestasi belajar siswa SMPN 1 Mejobo, dan (3) Mengetahui peran perhatian orangtua dan motivasi belajar terhadap prestasi belajar siswa SMPN 1 Mejobo.

\section{METODE PENELITIAN}

Penelitian studi kasus ini dilakukan di SMPN 1 Mejobo Kudus dengan metode penelitian dengan menggunakan metode penelitian kualitatif. Penelitian kualitatif yaitu penelitian yang bersifat deskriptif dan cenderung lebih menggunakan analisis. Dalam penelitian kualitatif peneliti bertolak dari data, memanfaatkan teori yang ada sebagai bahan penjelas, dan berakhir dengan suatu teori. Penelitian ini bertujuan untuk mendeskripsikan apa adanya mengenai peran keluarga terhadap prestasi belajar anak. Berdasarkan hal tersebut maka metode penelitian yang digunakan adalah metode naturalistik, yaitu penelitian yang bersumber pada aspek fenomenologi dan berusaha memahami arti peristiwa atau permasalahan dan hubungannya terhadap objek penelitian. Melalui prosedur penelitian yang menghasilkan data deskriptif analisis berupa pendapat dan persepsi serta perilaku dari responden yang dapat dilihat, dijadikan sebagai sumber data primer dalam penelitian ini. Teknik pengumpulan data di samping dengan menggunakan observasi juga dilakukan melalui deep interview. Penelitian ini termasuk jenis penelitian kualitatif karena bersifat fenomenologis.

Penelitian ini juga menggunakan metode wawancara. Wawancara adalah proses memperoleh keterangan untuk tujuan penelitian dengan tanya jawab bertatap muka antara interviewer dengan informan dengan menggunakan alat interview guide (panduan wawancara). Wawancara merupakan metode pengumpulan data dengan jalan tanya jawab sepihak yang dilakukan secara sistematis dan berlandaskan 
kepada tujuan penelitian. Wawancara yang dilakukan di penelitian ini yaitu dengan mewawancarai salah satu siswa SMPN 1 Mejobo Kudus dan salah satu keluarga dari siswa tersebut.

\section{PEMBAHASAN}

\section{Hakikat Keluarga}

Menurut Undang-Undang Perkawinan No. 1 tahun 1974, perkawinan adalah ikatan lahir serta batin antara seorang pria dengan seorang wanita sebagai suami istri dengan bertujuan membentuk keluarga (rumah tangga) yang berbahagia dan kekal berdasarkan Ketuhanan yang Maha Esa.

Keluarga adalah tempat yang pertama dan utama untuk pembentukan sikap dan pribadi anak. Apabila anak tumbuh dan dididik dalam lingkungan keluarga yang harmonis, saling menghargai diantara anggota keluarga maka akan menghasilkan masyarakat yang harmonis saling menghargai, saling mengasihi walaupun beda kepercayaan dan beda etnis dan kebudayaan. Masalah yang timbul di dalam keluarga secara garis besar karena tidak adanya komunikasi, saling pengertian.

\section{Komunikasi dalam Keluarga}

Komunikasi adalah salah satu hal yang penting yang dibutuhkan dalam sebuah keluarga. Bukan karena tanpa alasan, keluarga sebuah lembaga yang terbentuk karena adanya ikatan perkawinan. Di dalam hidup bersama suami istri sah karena pernikahan. Posisi keluarga atau rumah tangga ini sangat sentral seperti diungkapkan oleh Aristoteles (dalam Noor, 1983). Keluarga menjadi kelompok sosial pertama dan tempat belajar sebagai makhluk sosial.

Dalam suatu keluarga akan melahirkan keturunan. Dengan seiring waktu berjalan karakter anak akan terbentuk salah satunya melalui komunikasi antar anggota keluarga. Sangatlah penting orangtua dalam memberikan komunikasi yang efektif, agar anak lebih bertanggung jawab.
Dari hasil observasi dan wawancara kelompok yang dilakukan peneliti di SMPN 1 Mejobo Kudus, peneliti menemukan bahwa hampir 90 persen siswa kurang mendapat perhatian dari orangtua, sehingga prestasi proses belajar siswa masih tergolong rendah dan belum ada perubahan yang signifikan. Kurangnya perhatian orangtua diakarenakan beberapa faktor, antara lain yaitu orangtua terlalu sibuk, persepsi orangtua yang menganggap bahwa pendidikan adalah tanggungjawab sekolah saja, serta orangtua masih memiliki persepsi bahwa anak sekolah hanya akhirnya untuk kerja, bukan untuk mencari ilmu (Budi Santoso, 2019).

Ketika keluarga terbentuk, maka unsur di dalamnya ada suami, isteri dan anak sebagai penghuninya. Seluruh anggota saling berinteraksi satu sama lain dan menimbulkan dinamika kelompok. Terkadang karena untuk suatu kepentingan tertentu, bisa saja terjadi masalah dalam kelompok. Oleh karena itu, konflik dalam keluarga harus diminimalisir untuk menciptakan keluarga yang seimbang dan harmonis. Oleh karena itu salah satu faktor penting dalam keluarga adalah menjaga komunikasi yang baik dengan mengedepankan nilai sopan santun berbasis akhlakul karimah.

\section{Perhatian Orangtua dalam Pengasuhan anak}

Pada dasarnya setiap anak memiliki empat masalah besar yang tampak jelas di mata orangtuanya, yaitu out of law (tidak taat aturan, seperti susah belajar, susah menjalankan perintah, dan sebagainya); bad habit (kebiasaan buruk, seperti suka jajan, suka merengek, suka ngambek, dan sebagainya); maladjustment (penyimpangan perilaku), dan pause playing delay (masa bermain yang tertunda). Mengingat besarnya permasalahan yang dihadapi anak dalam pertumbuhan dan perkembangannya seperti, maka sudah sewajarnya jika orangtua terutama ibu memberikan perhatian, bimbingan, dan pengawasan yang lebih optimal kepada anak-anaknya (Siti Nurhidayah, 2008:4).

Beberapa penelitian telah banyak dilakukan tentang hubungan antara sikap orangtua dalam mengasuh dan mendidik anak. Salah satu penelitian menyebutkan bahwa peningkatan 
kemampuan intelektual anak yang paling tinggi ditemukan pada keluarga-keluarga yang dapat menerima anak sepenuhnya dan yang bersikap demokratis dalam pendidikan, jika dibandingkan dengan keluarga-keluarga yang cenderung menolak kehadiran anak dan yang bersikap otoriter dalam pendidikan. Penelitian lain melihat hubungan antara kreativitas anak dan sikap orangtua dalam pendidikan, yaitu dengan membandingkan anakanak yang kreatif dengan keluarga dari anak-anak yang kurang kreatif. Hasilnya menunjukkan bahwa ibu-ibu dari anak-anak yang kreatif mempunyai pendidikan yang lebih tinggi dan mereka lebih mementingkan otonomi (kebebasan) anak. Mereka memberi kebebasan pada anak untuk memilih teman-temannya sendiri, mengambil keputusan sendiri, dan mereka mendorong anak untuk mengembangkan minat dalam bidang tertentu dan dalam kegiatan di luar rumah. Para ibu juga lebih menyukai kebebasan dan mereka kurang puas dengan peran sebagai ibu rumah tangga saja (Siti Nurhidayah, 2008: 4).

Pada tataran lingkungan keluarga, peranan orangtua (ibu dan ayah) dan anggota keluarga lain di rumah sangat memengaruhi pembentukan sikap disiplin pada anak. Menurut Gunarsa (2009: 6), aspek lingkungan keluarga yang memengaruhi tingkah laku anak di antaranya adalah "contoh dari orangtua, kasih sayang orangtua, dan keutuhan keluarga". Adapun aktor lingkungan keluarga yang memengaruhi perkembangan anak didik yaitu: "perhatian dan kasih sayang dari orangtua, figur keteladanan orangtua bagi anak, dan keharmonisan keluarga" (Ihsan, 2005: 19). Peranan lingkungan keluarga terhadap perkembangan anak meliputi: "status sosio ekonomi, keutuhan keluarga, sikap dan kebiasaan orangtua dan status anak" (Gerungan, 2002: 185).

Dari uraian-uraian di atas, maka dapat dinyatakan bahwa faktor-faktor lingkungan keluarga yang memengaruhi anak didik terutama yang memengaruhi anak didik dalam hal pembentukan sikap disiplin meliputi perhatian dan kasih sayang orangtua, keutuhan orangtua, keharmonisan keluarga, dan sifat keteladanan atau contoh dari orangtua. Lingkungan keluarga merupakan media pertama dan utama yang secara langsung atau tidak langsung berperan terhadap perilaku dalam perkembangan anak didik, termasuk di dalamnya prestasi belajar peserta didik. Pendidikan keluarga adalah pondasi dari pendidikan anak selanjutnya. Hasil-hasil pendidikan yang diperoleh anak dalam keluarga menentukan pendidikan anak itu selanjutnya, baik di sekolah maupun di masyarakat (Halasan Simanullang dkk, 2017: 5).

Kebanyakan orangtua di kota Kudus itu adalah menyekolahkan anaknya di Boarding School di samping untuk benar mengawasi anak karena waktu orangtua yang sudah habis tersita untuk kesibukannya dalam bekerja, juga mendapat pengetahuan tambahan dan pola pengasuhan anak yang selama 24 jam, sehingga kegiatan anak dapat terkontrol (Budi Santoso, 2019).

\section{Proses Belajar Anak}

Belajar pada hakikatnya merupakan usaha yang dilakukan secara sadar untuk menghasilkan perubahan, menyangkut pengetahuan, keterampilan, sikap, dan nilai-nilai. Oemar Hamalik (2008) mendefinisikan belajar yaitu perubahan tingkah laku yang relatif mantap berkat latihan upaya dan pengalaman. Mengajar adalah penciptaan sistem alam lingkungan yang memungkinkan terjadinya proses belajar mengajar. Menurut Suryosubroto mengajar pada hakikatnya adalah melakukan kegiatan belajar, sehingga proses belajar mengajar dapat berlangsung secara efektif dan efisien. Suryosubroto melanjutkan proses belajar mengajar yaitu meliputi kegiatan yang dilakukan guru mulai dari perencanaan, pelaksanaan kegiatan sampai evaluasi dan program tindak lanjut yang berlangsung dalam situasi edukatif untuk mencapai tujuan tertentu yaitu pengajaran.

Dalam hal proses belajar anak di SMPN 1 Mejobo Kudus banyak terjadi dilema mengenai kebijakan membawa gadget, di satu sisi teknologi merupakan salah satu alat yang penting digunakan untuk belajar atau untuk mencari informasi, Selain itu, gadget pada anak banyak yang disalahgunakan oleh anak apabila tidak diawasi oleh gurunya, diantaranya adalah dipergunakan untuk mencari jawaban dari 
google. Jadi dalam hal ini, guru membolehkan membawa gadget tapi harus dengan pengawasan yang maksimal sehingga penyalahgunaan bisa diminimalisasi (Budi Santoso, 2019).

\section{Hubungan Peran Orangtua dengan Prestasi Anak}

Peran orangtua dalam pembentukan motivasi dan penguasaan diri (self regulatory) anak sejak dini dapat memberikan modal dasar bagi kesuksesan dan prestasi anak. Peran orangtua dalam pendidikan dapat dilihat dari dua pendekatan. Pertama, orangtua dapat mendukung perkembangan intelektual dan kesuksesan akademik anak dengan memberi mereka kesempatan dan memberi akses ke sumber pendidikan, seperti jenis sekolah yang dimasuki anak atau akses ke sumber pendidikan lainnya, seperti perpustakaan, perangkat audio-visual, teknologi dan sebagainya. Kedua, orangtua dapat membantu dalam perkembangan kecerdasan kognitif, afektif, dan psikimotor yang berperan pada pencapaian prestasi akademik anak dengan terlibat langsung dalam aktivitas pendidikan mereka (Halasan Simanullang, dkk, 2017).

Orangtua yang membimbing anak mengerjakan pekerjaan rumah, membacakan bukubuku tertentu kepada mereka dan memainkan permainan yang berhubungan dengan pendidikan cenderung memiliki anak yang lebih berprestasi di sekolah. Orangtua juga dapat mengajarkan anak mengenal dan memahami norma-norma dalam berhubungan dengan orang dewasa dan teman sebaya serta lingkungan sosial yang ada di sekitarnya (Halasan Simanullang, dkk, 2017).

Mengenai hubungan orangtua dengan anak di SMPN 1 Mejobo Kudus, para orangtua belum memberikan kepeduliannya kepada anak secara maksimal. Orangtua masih belum memahami perkembangan anak dan masih meiliki persepsi bahwa pendidikan anak adalah tugas sekolah dan tugas orangtua hanya mencukupi kebutuhan anak, termasuk kebutuhan pendidikan. Mirisnya lagi banyak orangtua yang yang lupa akan nama asli anaknya karena keseringan panggil nama panggilan dan dengan kesibukan orangtuanya, selain itu juga banyak orangtua yang tidak tau anaknya kelas berapa, dapat nilai berapa, sehingga akibatnya banyak siswa yang ketika menerima rapor hasil belajar banyak siswa yang menandatangani sendiri di buku rapornya itu (Budi Santoso, 2019). Oleh karena itu, peraturan menteri pendidikan yang menyarankan agar orangtua mengantarkan anaknya ke sekolah di hari pertama masuk sekolah, itu adalah sindiran bagi masyarakat yang banyak tidak peduli dengan perkembangan anaknya.

\section{KESIMPULAN}

Berdasarkan hasil penelitian dan pembahasan hasil penelitian di atas, maka dapat disimpulkan bahwa bahwa peran keluarga terhadap prestasi siswa di SMPN 1 Mejobo Kudus masih terbilang sangat rendah. Hal ini dapat diidentifikasi dari hasil observasi serta wawancara yang dilakukan bahwa hampir 90\% orangtua masih tidak ambil peduli terhadap perkembangan pendidikan anak. Orangtua masih memandang bahwa tugas mendidik anak merupakan tugas sekolah. Dengan alasan kesibukan dan setumpuk tugas pekerjaan, orangtua abai terhadap perkembangan prestasi anaknya. Hal ini berdampak pada menurunnya prestasi siswa dalam mata pelajaran Ilmu Pengetahuan Sosial (IPS).

\section{DAFTAR PUSTAKA}

Chasiyah, Chadidjah, \& Legowo, Edy. (2009). Perkembangan Peserta Didik. Surakarta: UNS Press

Gunarsa, S.D. (2009). Psikologi untuk Keluarga. Jakarta: Gunung Mulia

Gerungan, W.A. (2004). Psikologi Sosial. Bandung: Refika Aditama

Halasan Simanullang, dkk. (2017). Peran Lingkungan Keluarga Dalam Meningkatkan Prestasi Belajar Siswa, Program Studi Pendidikan Dasar, Pascasarjana Universitas Negeri Malang

Ihsan, F. (2005). Dasar-dasar Kependidikan. Jakarta: PT Rineka Cipta 
Ni Nyoman Wulan Swidiana Sari Widana. (2016). Peran Disiplin Belajar Dan Lingkungan Keluarga Terbadap Prestasi Belajar Ilmu Pengetabuan Sosial Siswa Kelas Viii Smp Negeri 3 Singaraja, (Singaraja: Prodi Pendidikan Ekonomi, Fakultas Ekonomi dan Bisnis Universitas Pendidikan Ganesha

Hamalik, Oemar. (2008). Proses Belajar Mnegajar. Jakarta: Bumi Aksara

Budi Santoso, Wawancara, Mejobo, 11 Mei 2019

Sardiman, A.M. (2004). Interaksi dan Motivasi Belajar Mengajar. Jakarta: Rajawali Pers

Siska Eko Mawarsih, dkk. (2013). Peran Perhatian Orangtua Dan Motivasi Belajar Terhadap Prestasi Belajar Siswa Sma Negeri Jumapolo, JUPE UNS, Vol. 1, No. 3, (Surakarta: Pendidikan Ekonomi-BKK Akuntansi, FKIP Universitas Sebelas Maret)
Siti Nurhidayah. (2008). Peran Ibu Bekerja Dan Peran Ayah Dalam Coparenting Terhadap Prestasi Belajar Anak. Jurnal Soul, Vol. 1, No. 2, September

Slameto. (2010). Belajar dan Faktorfaktor yang Mempengarubinya, Jakarta: Rineka Cipta

Syah, M. (2010). Psikologi Pendidikan: Dengan Pendekatan Baru. Bandung: PT. Remaja Rosdakarya

Nasution, Thamrin dan Nasution, Nurhalijah. (2008) Peranan Orangtua dalam Meningkatkan Prestasi Belajar Anak. Jakarta: PT. BPK Gunung Mulia

Walgito, Bimo. (2004) Pengantar Psikologi Umum. Yogyakarta: Andi Offset

Soemanto, Wasty. (1990). Psikologi Pendidikan, Jakarta: Rineka Cipta 